\title{
Diet of the ichthyofauna associated with marginal vegetation of a mangrove forest in southeastern Brazil
}

\author{
Michéle de O. D. A. Corrêa \& Virgínia S. Uieda
}

Departamento de Zoologia, Instituto de Biociências, CP 510, Universidade Estadual Paulista - UNESP, 18618-000 Botucatu, São Paulo, Brasil. (modacbr@gmail.com; vsuieda@ibb.unesp.br)

\begin{abstract}
The objective of this study was to analyze the diet of fish species that use the mangrove vegetation for shelter and feeding in a river southeastern Brazil. The fieldwork, including collecting and underwater observations, was carried out in the dry (July and August 2004) and in the rainy season (February and March 2005) in order to assess the existence of seasonal variation in the diets. Seven kinds of food items were consumed, two of plant origin and five of animal origin. Crustaceans predominated in the diet of most species, either in the form of unidentified fragments or discriminated in eight groups. The predominance of species using mainly a single food source (crustaceans, principally Ostracoda and Tanaidacea) and the existence of seasonal variation in the diets of some species became very evident in the analysis food niche breadth, with a predominance of dietary specialists. In the Rio da Fazenda mangrove, the submersed marginal vegetation was used by the ichthyofauna as a locale for foraging, and principally as cover by bottom-feeding species. These species may be using the vegetation for protection from aerial and aquatic predators, or even from the pull of the current during the turn of the tide. In the study area, the great diversity of crustaceans constitutes an important food source for most fish species which adjusted their diet according to seasonal changes in food availability and to interactions with other species.
\end{abstract}

KEYWORDS. Feeding habit, seasonal variation, ontogenetic variation, niche breadth.

RESUMO. Dieta da ictiofauna associada à vegetação marginal de um mangue no sudeste do Brasil. O presente trabalho objetivou analisar a dieta das espécies de peixes que utilizam a vegetação do mangue do Rio da Fazenda como local de abrigo e alimentação em um rio do sudeste do Brasil. O trabalho de campo, incluindo coleta e observação subaquática das espécies, foi realizado na estação seca (julho e agosto de 2004) e na chuvosa (fevereiro e março de 2005) com o objetivo de verificar a existência de variação sazonal na dieta. Sete tipos de itens alimentares foram consumidos pelas espécies, dois de origem vegetal e cinco de origem animal. Os crustáceos predominaram na dieta da maioria das espécies, seja na forma de fragmentos não identificados ou discriminados em oito grupos. O predomínio de espécies utilizando essencialmente uma única fonte alimentar (crustáceos, principalmente Ostracoda e Tanaidacea) e a existência de variação sazonal na dieta de algumas espécies ficaram bem evidentes na análise de amplitude do nicho alimentar, com um predomínio de espécies especialistas. No mangue do Rio da Fazenda, a vegetação marginal submersa foi utilizada pela ictiofauna como local de forrageamento e, principalmente, como cobertura para espécies que buscavam alimento no substrato do fundo. Estas espécies podem estar utilizando a vegetação como proteção contra predadores aéreos e aquáticos, ou mesmo contra o arraste no período de mudança das marés. Na área de estudo, a grande diversidade de crustáceos constituiu uma importante fonte de alimento para a maioria das espécies, as quais ajustaram sua dieta em função de variações sazonais na oferta e em função das interações com outras espécies.

PALAVRAS-CHAVE. Hábito alimentar, variação sazonal, variação ontogenética, amplitude de nicho.

Tropical and subtropical mangrove forests are important nurseries for many species of fishes (WRIGHT, 1986; Robertson \& Duke, 1987; Chong et al., 1990). They offer food and shelter for the larval and juvenile stages (ChAVEs \& Bouchereau, 1999). These coastal ecosystems are inhabited by populations of both marine and freshwater fishes, which have strategies for the use of these regions. Some marine fishes use the estuaries during their migration to more saline waters, with the transition to the estuary facilitating the adaptation of the young fish to the marine environment (Morin \& WHORISKEY, 1992).

The young of many species, including some of commercial importance, are found exclusively in mangroves (ThAYer et al., 1987; RoberTSOn \& Duke, 1990). However, while their role as a nursery for young fish is well understood, it is still unclear why mangroves are attractive to adult fish (LAEGDSGAARD \& JOHNSON, 1995, 2001). Because of the strong continental influence, seasonal oscillations in the physical and chemical parameters in this kind of environment may influence the permanence or impermanence of fish populations in an estuary during the course of their life cycles (CHAVES \& Отто, 1999).

The high densities of fish and motile macroinvertebrates in the mangrove vegetation appear to be related to the greater protection provided by this vegetation. The aerial roots, tree trunks, and fallen branches of the mangrove forests attract fish, providing refuge from predation and more food availability (LAEDSGAARD \& Johnson, 2001). Fish may be more abundant in these habitats, even in the presence of predators because the increased structural complexity of the tree branches covered by algae affords them more shelter, and thus less risk of predation. Other works have demonstrated a close relationship between the increase in complexity and decrease in the incidence of predation in other kinds of vegetated aquatic habitats (HECK JR. \& THOMAN, 1981).

However, little is known of the abundance and diversity of the ichthyoplankton in estuaries, nor of the spatial and temporal variations of the fish communities (Morais \& Morais, 1994). Little is known about which species remain in the mangroves during low tide, and 
their survival strategies (BARLETTA et al., 2000). In Brazil, knowledge about the ichthyofauna of estuaries and coastal zones is particularly limited. For example, in the Brazilian Northeast, the first study with the objective of obtaining basic information about the estuarine system was initiated in 1996 (BARLETTA-BERGAN et al., 2002).

Conservation of mangrove forests is highly important for the maintenance of biodiversity of this important link between continental water bodies and the sea. Destruction of mangroves can also damage traditional fisheries through loss of the food supplied by this system, one of its principal roles. Unfortunately, although the estuaries and coastal regions of Brazil are important for feeding, growth and reproduction of a large number of marine organisms and especially for different species of fishes of high commercial importance, knowledge on the ichthyofauna of these environments is still quite limited (Paiva Filho \& Toscano, 1987; BARLETTA-Bergan et al., 2002).

The objective of this study was to analyze the diet of fish species that use mangrove vegetation as a locale for shelter and feeding. The influence of seasonal oscillations on their diets was also analyzed.

\section{MATERIAL AND METHODS}

The study was carried out in the mangrove forest of the Rio da Fazenda (23⒊ $31^{\prime}-23^{\circ} 34^{\prime}$ 'S, $\left.45^{\circ} 02^{\prime}-45^{\circ} 05^{\prime} \mathrm{W}\right)$, located in the Serra do Mar State Park, Picinguaba Unit (Núcleo Picinguaba) (Fig. 1). The Picinguaba Unit is situated in the state of São Paulo and preserves all the environments that compose the coastal ecosystem complex: beach, rocky shore, "restinga" (coastal dune forest), mangroves, coastal plain forest and hillside forest. Rio da Fazenda is a coastal river, about $6 \mathrm{~km}$ long. Its headwaters are on the slopes of the Serra do Mar, and its mouth at Fazenda Beach; its course is entirely contained within the boundaries of the Picinguaba Unit.

Three stretches of mangrove were selected for study of their ichthyofauna (Fig. 1): a lower stretch, with higher salinity $(6.3 \pm 3.5$ and $3.5 \pm 0.5 \mathrm{ppm}$, in the dry and rainy seasons respectively); an upper stretch, with low salinity $(1.1 \pm 0.7$ and $0.5 \pm 0.2 \mathrm{ppm})$; and a middle stretch, with intermediate salinity $(4.0 \pm 2.0$ and $2.1 \pm 0.4 \mathrm{ppm})$. Although these stretches showed distinct salinity values, the dissolved oxygen contents $(6.0 \pm 0.9$ and $5.4 \pm 0.5$ $\mathrm{mgO}_{2} \mathrm{l}^{-1}$, in the dry and rainy seasons respectively) and water temperatures $\left(19.7 \pm 1.2\right.$ and $\left.24.0 \pm 0.7^{\circ} \mathrm{C}\right)$ were similar. The mangrove vegetation in these stretches is composed principally of Hibiscus pernambucensis (Malvaceae), Laguncularia racemosa (Combretaceae) and Eugenia sp. (Myrtaceae).

Fieldwork was carried out during four excursions, two in the dry season (July and August 2004) and two in the rainy season (February and March 2005). In a fiveday period during each excursion, the fish species present among and under the submerged branches of the vegetation were observed and collected for 10 meters along the margin of each of the three stretches. The objective of the observations was to ascertain the sites where the species were foraging. The specimens collected were used for checking taxonomic identification and for

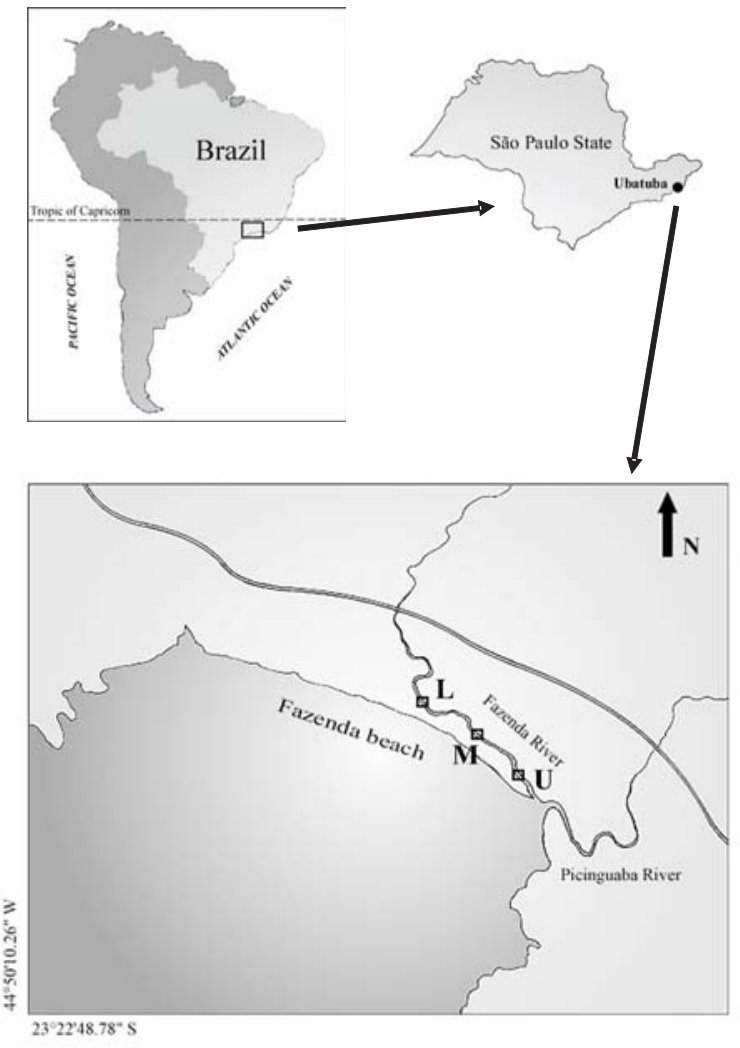

Fig 1. Position of the three stretches (high, median and low ranges of salinity) sampled in the Rio da Fazenda mangrove, southeastern Brazil (only the main channels of the Rio da Fazenda and the Rio Picinguaba are represented). (U, upper stretch; M, middle stretch; L, lower stretch).

diet analysis. Each day, the stretches were visited during the morning, always during full moon and at low tide, for about one hour in each stretch, so that all three stretches could be visited before the turn of the tide. During this period, we made underwater observations, collections, and environmental measurements (dissolved oxygen, temperature and salinity, by means of a water checker analyzer).

The dive sessions were done in the first four days of each trip, by free-diving with a half-face mask, snorkel, and dark-colored, insulating neoprene wetsuit and boots ("snorkeling" cf. SABINO, 1999), totaling approximately 13 hours of observations in the dry season, and 6.5 hours in the rainy season. The observations were recorded with a PVC plaque and eraser-pencil (SABINO, 1999); data on fishes swimming under the vegetation, and their behavior were recorded. During a diving session, fish were collected with a small hand net and fixed in $10 \%$ formalin. In March 2005, only collections were made, because the mangrove was full of algae that float by any movement in the water, which made it impossible to make observations.

On the fifth day of fieldwork, the fish were caught with a seine net ( $1 \times 4 \mathrm{~m} ; 2 \mathrm{~mm}$ mesh). The specimens were fixed in $10 \%$ formalin. Collecting consisted of pulling the net toward the shore, enclosing and suspending the vegetation, in short 2-meter stretches; the collection was repeated in the same place until no more fish were caught. The same procedure was repeated, moving upstream, along the entire 10-meter stretch worked. 
The species collected were identified (FIGUEIREDO \& Menezes, 1980, 2000; Menezes \& Figueiredo, 1980, 1985) and vouchers are in the fish collections of the Museu de Zoologia da Universidade de São Paulo (MZUSP 93928-93939). For each specimen the standard length (SL) was noted before its gut was removed. Diets were analyzed separately by season (dry and rainy), based on the stomach contents (for those species without a differentiated stomach, the first third of the intestine was analyzed) and the food items were identified to the lowest possible taxonomic category. Three methods were used: frequency of occurrence, biovolume and numerical frequency. Frequency of occurrence indicates the presence or absence of an item (HySLOP, 1980), and is calculated from the number of fish in which the item occurred, in relation to the total occurrences of all items. Biovolume (Esteves \& GALETTI JR., 1995) corresponds to the relation between the area occupied by a certain item and the total area occupied by all items, the area being determined with the aid of a millimeter grid. Numerical frequency is the percentage of the number of individuals of a certain item present in the stomach contents (HySLOP, 1980), calculated in relation to the total of individuals of all groups consumed.

The data of frequency of occurrence $(F)$ and biovolume (V) were used to calculate the Feeding Index (FI) by the formula (KAWAKAMI \& VAZZOLER, 1980): FI = $(\mathrm{FV}) / \Sigma(\mathrm{FV})$. The feeding habit of each species was defined using the dietary items with Feeding Index equal or higher than $20 \%$, considering these foods as predominant in the diet.

For the crustaceans consumed (excluding the fragments), the numerical method $(\mathrm{N})$ was also used to calculate the Relative Index of Importance (RII). The crustacean group with RII equal or higher than $15 \%$ was considered predominant in the diet. This index was calculated using the formula (PINKAS et al., 1971): RII = $(\mathrm{N}+\mathrm{V}) \mathrm{F}$.

To compare diets among different fish species or within the same species in the dry and rainy seasons, the calculated values of FI and RII were transformed to relative values $(\%)$

For the fish species with six or more individuals with gut contents and which showed more than four food categories, Spearman's Rank Coefficient $(\alpha<0.05)$ was applied to the data for frequency of occurrence, to test for an association or lack of association between the diets during the two seasons of the year (STATSOFT, 2001). This analysis was applied to the data for the general diet (all items) and specific diet (crustacean groups). For those fish species with fewer than four food categories, Kendall's Correlation Coefficient was applied $(\alpha<0.05)$ (Statistica, 2001).

The chi-square test was applied to the data for frequency of occurrence in a way to test for ontogenetic variation in the diet. Ontogenetic variation was analyzed only for fish species of which we collected six or more individuals in each size class. The interval and number of size classes were determined according to the extent of fish length and the number of individuals by size class.

To visualize the seasonal organization of the ichthyofauna in relation to the general diet (FI\%) and specific diet (RII\%), we used the Bray-Curtis measure of dissimilarity and cluster analysis by the program Biodiversity Professional version 2 (PIELOU, 1984).

Food overlap was analyzed for the fish species grouped into bottom-feeders and vegetation feeders, according to the foraging site as defined from underwater observations. Overlap was calculated for the general diet and for the types of crustaceans consumed, and separately for the dry and rainy seasons. To make this calculation, we used Horn's index (KREBS, 1989), which can vary from 0 , when no food category is shared by species, to 1, when the diets of two species are identical. Overlap values $\geq 0.7$ were considered significant.

For those species which consumed more than two kinds of food items, it was possible to calculate the food niche breadth (KREBS, 1989). This index allows quantitative evaluation of the degree of specialization of the organisms in using environmental resources (KREBS, 1989). The calculation was done using Levins's standardized niche breadth measure, applied to the data for the general diet (FI\%) and for the specific diet (RII\%) separately for the dry and rainy seasons.

\section{RESULTS}

The diet of 14 fish species collected in the Rio da Fazenda mangrove in the dry and rainy seasons was analyzed (Tab. I), except for Mugil curema (Valenciennes, 1836) because all individuals collected had their stomachs empty.

Analysis of the general diet (FI). The fish species analyzed consumed seven kinds of food items, two of plant origin and five of animal origin. Crustaceans predominated in the diet of most species (Figs. 2 and 3), either in the form of unidentified fragments, or discriminated in eight groups (Tab. II).

Five of the six species sampled in both seasons of the year ingested predominantly crustaceans, in both seasons (Fig. 2). However, this apparent seasonal similarity in diet was confirmed by non-significant Spearman's correlations only for Lupinoblennius paivai (Pinto, 1958) (0.66), Ctenogobius boleosoma (Jordan \& Gilbert, 1882) (0.78) and Ctenogobius shufeldti (Jordan \& Eigenmann, 1887) (0.19).

For Bathygobius soporator (Valenciennes, 1837), a significant seasonal variation occurred (Spearman $=0.04)$, with crustaceans predominating in the dry season and with a more diversified diet in the rainy season (Fig. 2). For Citharichthys spilopterus Günther, 1862 although the seasonal variation was not significant (Spearman $=0.60$ ), the percentage of fish in the diet was higher in the rainy season.

Although Microphis lineatus (Kaup, 1856) consumed different items in the two seasons, its diet was defined from only one individual caught in each season, which made impossible to analyze the seasonal variation in the diet.

Of the seven species that occurred in only one season of the year (Fig. 3), three ingested mainly crustaceans, and two, aquatic insects. The other two species showed a more diversified, carnivorous diet, with a predominance of aquatic insects in Centropomus 
Table I. Fish species collected in the mangrove forest of the Rio da Fazenda in the dry season (July and August 2004) and the rainy season (February and March 2005). Number (N) and size (SL, minimum and maximum standard length in millimeters) of individuals used in the diet analysis (stomach contents). The species acronyms will be used in the following figures and tables.

\begin{tabular}{|c|c|c|c|c|c|}
\hline \multirow[t]{2}{*}{ Family/Species } & \multirow[t]{2}{*}{ Acronym } & \multicolumn{2}{|c|}{ Dry season } & \multicolumn{2}{|c|}{ Rainy season } \\
\hline & & $\mathrm{N}$ & SL & $\mathrm{N}$ & SL \\
\hline Achiridae & & & & & \\
\hline $\begin{array}{l}\text { Trinectes paulistanus (Miranda-Ribeiro, 1915) } \\
\text { Bleniidae }\end{array}$ & Tpau & & & 4 & $12-24$ \\
\hline $\begin{array}{l}\text { Lupinoblennius paivai (Pinto, 1958) } \\
\text { Centropomidae }\end{array}$ & Lpai & 32 & $12-31$ & 2 & $18-25$ \\
\hline $\begin{array}{l}\text { Centropomus parallelus Poey, } 1860 \\
\text { Eleotridae }\end{array}$ & Cpar & 6 & $13-29$ & & \\
\hline $\begin{array}{l}\text { Eleotris pisonis (Gmelin, 1789) } \\
\text { Gerreidae }\end{array}$ & Epis & 1 & 20 & & \\
\hline $\begin{array}{l}\text { Eucinostomus melanopterus (Bleeker, 1863) } \\
\text { Gobiidae }\end{array}$ & Emel & & & 5 & $14-47$ \\
\hline Bathygobius soporator (Valenciennes , 1837) & Bsop & 15 & $26-59$ & 24 & $13-67$ \\
\hline Ctenogobius boleosoma (Jordan \& Gilbert, 1882) & Cbol & 5 & $18-26$ & 42 & $22-35$ \\
\hline $\begin{array}{l}\text { Ctenogobius shufeldti (Jordan \& Eigenmann, 1887) } \\
\text { Mugilidae }\end{array}$ & Cshu & 4 & $21-31$ & 7 & $19-40$ \\
\hline $\begin{array}{l}\text { Mugil curema (Valenciennes, 1836) } \\
\text { Paralichthyidae }\end{array}$ & Mcur & & & 15 & $20-22$ \\
\hline $\begin{array}{l}\text { Citharichthys spilopterus Günther, } 1862 \\
\text { Poeciliidae }\end{array}$ & Cspi & 5 & $13-61$ & 6 & $23-160$ \\
\hline $\begin{array}{l}\text { Poecilia vivipara Bloch \& Schneider, } 1801 \\
\text { Syngnathidae }\end{array}$ & Pvi & & & 1 & 18 \\
\hline Microphis lineatus (Kaup, 1856) & Mlin & 1 & 129 & 1 & 113 \\
\hline $\begin{array}{l}\text { Pseudophallus mindii (Meek \& Hildebrand, 1923) } \\
\text { Tetraodontidae }\end{array}$ & Pmin & & & 1 & 47 \\
\hline Sphoeroides greeleyi (Gilbert, 1900) & Sgre & & & 2 & $15-18$ \\
\hline
\end{tabular}

Table II. Alimentary overlap matrices (Horn's index) for fish species that forage on the bottom or in the vegetation of the Rio da Fazenda mangrove, during the dry and rainy seasons. The overlap index was calculated using the values of the Feeding Index (FI\%) of each food item. Values above 0.7 were considered significant. Acronyms for fish species as in Table I.

\begin{tabular}{|c|c|c|c|c|c|c|c|c|}
\hline \multicolumn{9}{|c|}{ Dry season } \\
\hline \multicolumn{5}{|c|}{ Bottom } & & \multicolumn{3}{|c|}{ Vegetation } \\
\hline & Bsop & Cspi & Cbol & Cshu & & Lpai & Mlin & Pmin \\
\hline Bsop & & & & & Lpai & & & \\
\hline Cspi & 0.959 & & & & Mlin & 0.037 & & \\
\hline Cbol & 0.969 & 0.971 & & & Pmin & 0.995 & 0.000 & \\
\hline Cshu & 0.477 & 0.472 & 0.526 & & Cpar & 0.624 & 0.697 & 0.593 \\
\hline Epis & 0.000 & 0.120 & 0.000 & 0.000 & & & & \\
\hline
\end{tabular}

\begin{tabular}{|c|c|c|c|c|c|c|c|c|c|}
\hline \multicolumn{10}{|c|}{ Rainy Season } \\
\hline & \multicolumn{4}{|c|}{ Bottom } & & & \multicolumn{3}{|c|}{ Vegetation } \\
\hline & Bsop & Cspi & Cbol & Cshu & Emel & & Lpai & Mlin & Sgre \\
\hline$\overline{\text { Bsop }}$ & & & & & & & & & \\
\hline Cspi & 0.789 & & & & & Mlin & 0.489 & & \\
\hline Cbol & 0.662 & 0.662 & & & & Sgre & 0.489 & 1.000 & \\
\hline Cshu & 0.739 & 0.373 & 0.652 & & & Pviv & 0.074 & 0.000 & 0.000 \\
\hline Emel & 0.520 & 0.677 & 0.939 & 0.494 & & & & & \\
\hline Tpau & 0.442 & 0.356 & 0.555 & 0.334 & 0.500 & & & & \\
\hline
\end{tabular}

parallelus Poey, 1860 and polychaetes in Trinectes paulistanus (Miranda-Ribeiro, 1915) (Fig. 3).

Grouping the species by similarity in the general diet (Fig. 4) indicated the presence of three groups of species in the dry season and four in the rainy season. Although in both seasons the largest group consisted of species that fed mainly on crustaceans (Group I), in the rainy season the carnivorous diet was more diversified, with additions of polychaetes, aquatic insects and fish in the diets of some species (Fig. 4).

The underwater observation established that the majority of the species observed foraged on the bottom, few caught food among the submersed vegetation and none used both substrates for foraging. Because of this spatial difference in feeding, the analysis of dietary overlap from the general diet of these species in the dry and rainy seasons was carried out by considering separately the species which foraged on the bottom and in the vegetation (Tab. II). For the bottom-feeding species, the percent of high overlap values $(>0.7)$ was higher in the dry season $(30 \%)$ than in the rainy season $(20 \%)$. However, all the dietary overlaps of the dry season corresponded to Group I species in the similarity dendrogram; whereas in the rainy season they corresponded to Groups I and II (Fig. 4). Of those species which sheltered and fed among the vegetation, in both seasons only a pair of species showed significant overlap (16.7\%), corresponding to the Group I of the similarity dendrogram.

Analysis of the specific diet (Relative Index of Importance). Concerned to the eight kinds of crustaceans consumed by the fishes of the Rio da Fazenda mangrove, 

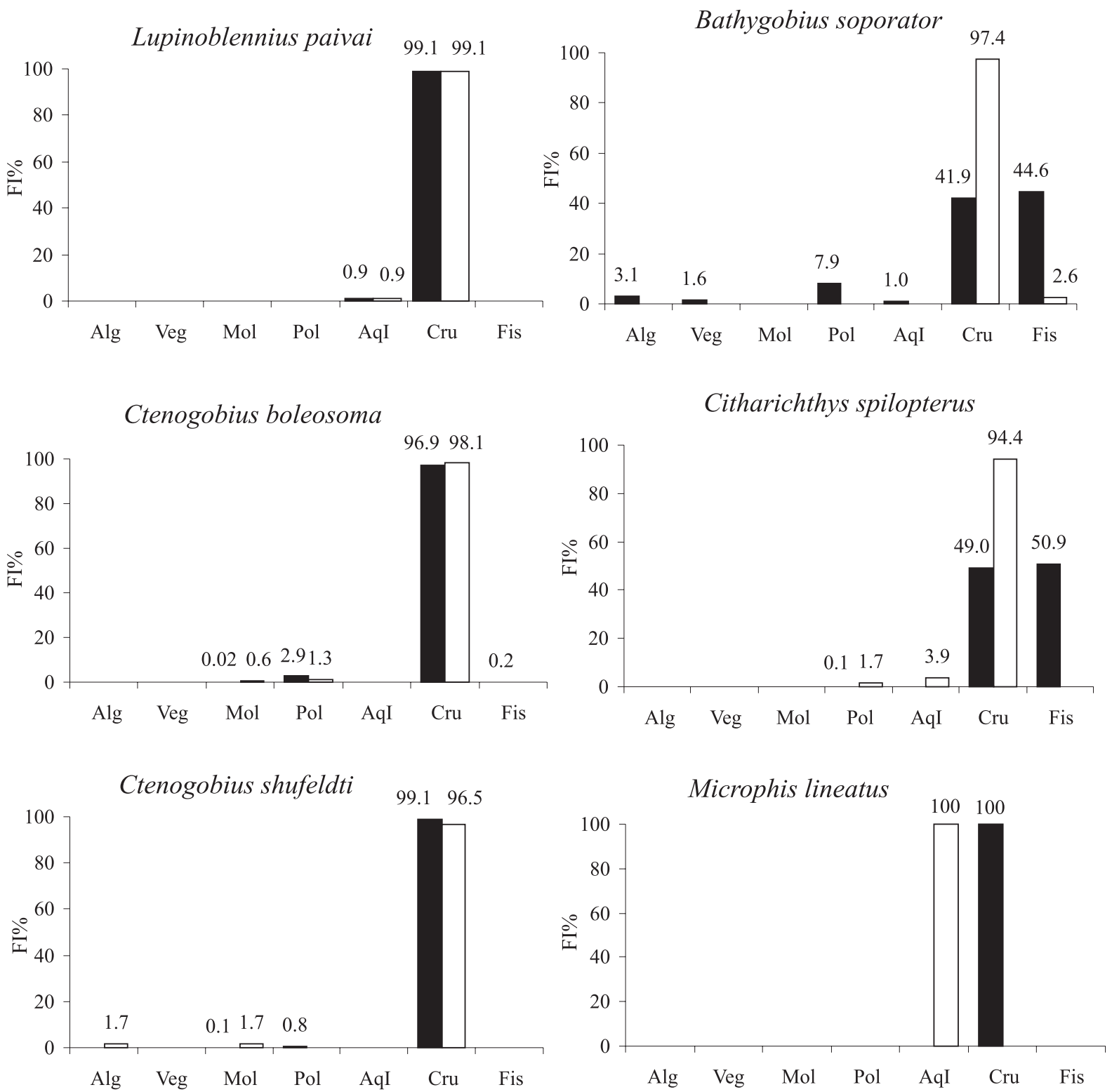

Fig. 2. Feeding Index (FI\%) of all food items consumed by fish species in the Rio da Fazenda mangrove during the dry season (white bars, July and August 2004) and rainy season (black bars, February and March 2005). (Alg, Algae; AqI, Aquatic Insects; Cru, Crustacea; Fis, Fish; Mol, Mollusca; Pol, Polychaeta; Veg, plant matter).

ostracods and tanaidaceans occurred in the highest percentage in the majority of cases analyzed (Tab. III).

Three of the five fish species that occurred in both seasons (Tab. III) did not show seasonal variation in diet. Bathygobius soporator and L. paivai consumed mainly tanaidaceans (Spearman $=0.49$ and 0.06, respectively), and C. boleosoma mainly ostracods (0.06). Of the species with seasonal difference in diet, $C$. spilopterus consumed more ostracods in the dry season and tanaidaceans in the rainy season; whereas $C$. shufeldti consumed both kinds of crustaceans in the dry season, and predominantly ostracods in the rainy season. However, this apparent seasonal variation was not confirmed statistically by Spearman's correlations $(0.58$ and 0.11 , respectively).
Of the five species analyzed only in one season, Eucinostomus melanopterus (Bleeker, 1863), C. parallelus and T. paulistanus consumed mainly one kind of crustacean (copepods by the first two species, and amphipods by the last), whereas Sphoeroides greeleyi (Gilbert, 1900) consumed a high percentage of ostracods and isopods (Tab. III). The diet of Pseudophalus mindii (Meek \& Hildebrand, 1923) was more generalist, including copepods, isopods and amphipods in very similar proportions.

Grouping of the species by similarity of the kinds of crustaceans consumed indicated the presence of four groups (Fig. 5). In both seasons, groups I and II ate mostly tanaidaceans and ostracods. This similarity analysis also revealed the seasonal variation of $C$. spilopterus and $C$. shufeldti. 

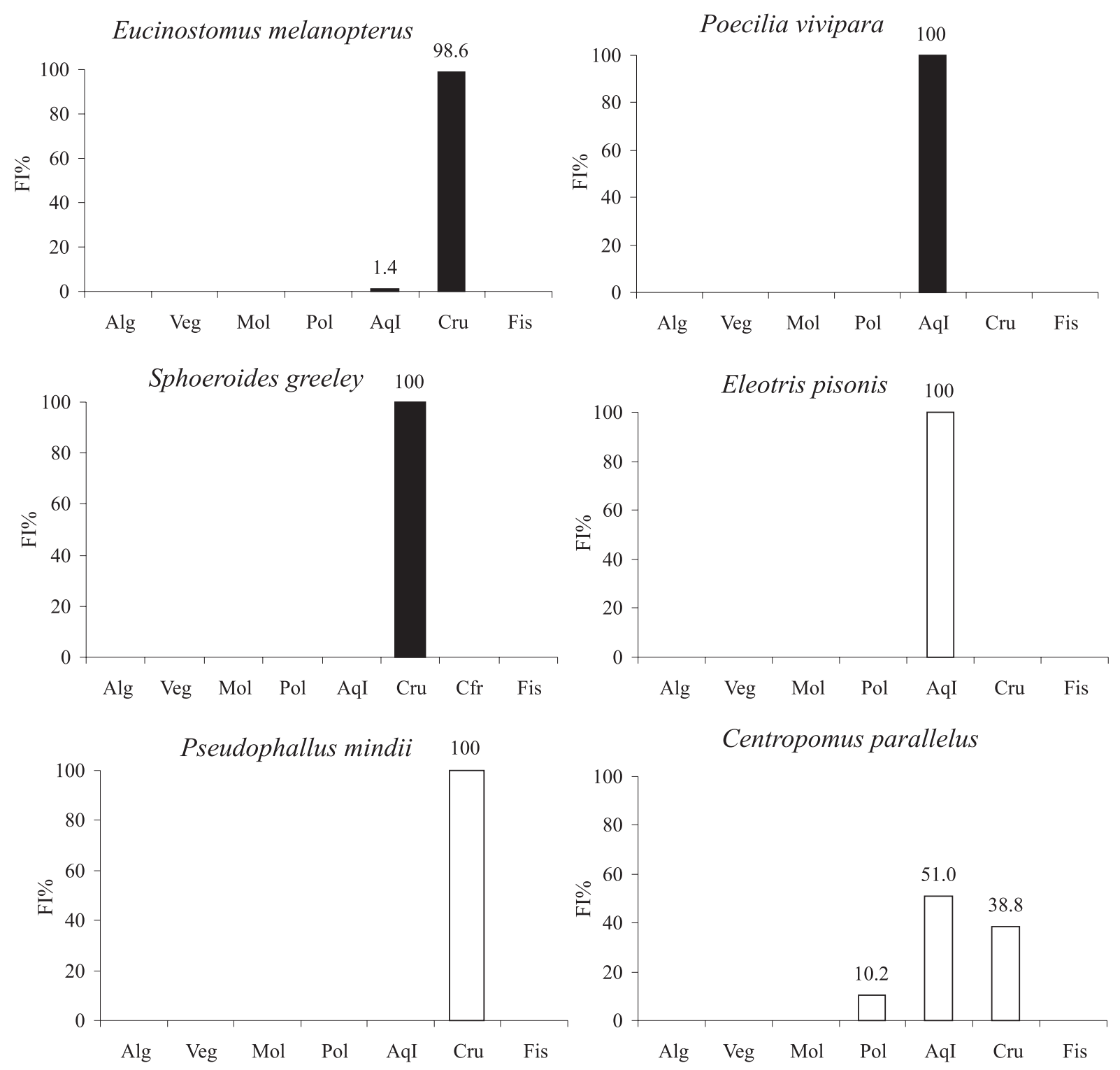

\section{Centropomus parallelus}

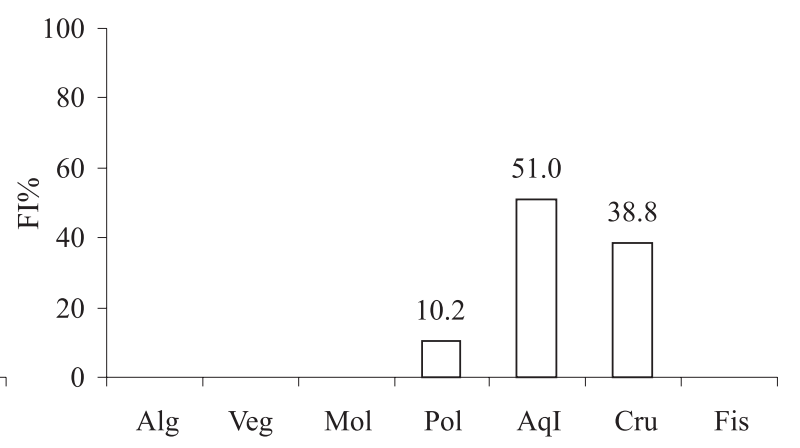

Trinectes paulistanus

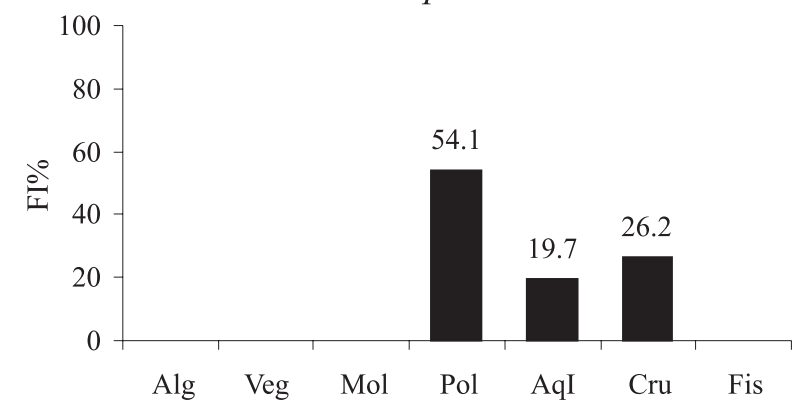

Fig. 3. Feeding Index (FI\%) of all food items consumed by fish species in the Rio da Fazenda mangrove, only in the dry season (white bars, July and August 2004) or in the rainy season (black bars, February and March 2005). (Alg, Algae; AqI, Aquatic Insects; Cru, Crustacea; Fis, Fish; Mol, Mollusca; Pol, Polychaeta; Veg, plant matter).

The seasonal analysis of food overlap based on the kinds of crustaceans ingested by the fishes was also carried out considering separately the species that foraged on the bottom and among the vegetation (Tab. IV). The bottom-feeders showed a higher percentage of significant overlap in the dry season (83.3\%) than in the rainy season $(13.3 \%)$. In the rainy season, of the two pairs of species with a high overlap value, one belongs to Group I of the dendrogram, which consumed mainly tanaidaceans, and one to Group II, with a higher 
Table III. Relative index of importance (RII\%) of the crustaceans consumed by the fish species of the Rio da Fazenda mangrove, during the dry season (DS, July and August, 2004) and the rainy season (RS, February and March, 2005). Acronym for fish species as in Table I.

\begin{tabular}{|c|c|c|c|c|c|c|c|c|c|c|c|c|c|c|c|}
\hline Groups of & Bsop & Bsop & Cspi & Cspi & Cbol & Cbol & Cshu & Cshu & Lpai & Lpai & Cpar & Emel & Sgre & Tpau & Pmin \\
\hline Crustaceans & DS & RS & DS & $\mathrm{RS}$ & DS & RS & DS & RS & DS & $\mathrm{RS}$ & DS & $\mathrm{RS}$ & RS & $\mathrm{RS}$ & DS \\
\hline Ostracoda & 24.1 & 0.2 & 74.0 & & 74.1 & 99.7 & 56.6 & 90.2 & & & & & 56.5 & & \\
\hline Copepoda & & & 5.3 & & & & & & & & 100.0 & 91.7 & & & 22.3 \\
\hline Caridea & & 8.4 & & 1.4 & & & & & & & & & & & \\
\hline Megalopa & & 1.6 & & 10.5 & & & & & & & & & & & \\
\hline Portunidae & & 3.4 & & & & & & & & & & & & & \\
\hline Tanaidacea & 74.2 & 64.8 & 9.6 & 69.4 & 25.9 & 0.2 & 43.4 & 9.5 & 84.9 & 87.5 & & 8.3 & 14.4 & & \\
\hline Isopoda & 1.7 & 19.2 & 4.1 & 17.5 & & 0.1 & & 0.3 & 15.0 & 12.5 & & & 29.1 & 33.3 & \\
\hline Amphipoda & & 2.4 & 7.0 & 1.2 & & & & & 0.1 & & & & & 100.0 & 44.4 \\
\hline Total of groups & 3 & 7 & 5 & 5 & 2 & 3 & 2 & 3 & 3 & 2 & 1 & 2 & 3 & 1 & 3 \\
\hline
\end{tabular}

Tabela IV. Alimentary overlap matrices (Horn's index) for fish species that forage on the bottom or in the vegetation of the Rio da Fazenda mangrove, during the dry (July and August, 2004) and rainy seasons (February and March, 2005). The overlap index was calculated using the values of the relative index of importance (RII\%) of the crustaceans consumed (Table III). Values above 0.7 were considered significant. Acronym for fish species as in Table I.

\begin{tabular}{|c|c|c|c|c|c|c|}
\hline \multicolumn{7}{|c|}{ Dry season } \\
\hline \multicolumn{4}{|c|}{ Bottom } & \multicolumn{3}{|c|}{ Vegetation } \\
\hline & Bsop & Cspi & Cbol & & Lpai & Pmin \\
\hline Cspi & 0.635 & & & Pmin & 0.226 & \\
\hline Cbol & 0.808 & 0.890 & & Cpar & 0.006 & 0.483 \\
\hline Cshu & 0.913 & 0.825 & 0.975 & & & \\
\hline
\end{tabular}

\begin{tabular}{lcccccc} 
& & & & Rainy season & & Vegetation \\
\hline & Bsop & Cspi & Cbol & Cshu & Emel & Sgre \\
Cspi & 0.933 & & & & Spre & 0.483 \\
Cbol & 0.027 & 0.018 & & & & \\
Cshu & 0.226 & 0.220 & 0.956 & & & \\
Emel & 0.187 & 0.190 & 0.007 & 0.089 & & \\
Tpau & 0.082 & 0.047 & 0.000 & 0.000 & 0.000 & \\
\hline
\end{tabular}

consumption of ostracods (Fig. 5, Tab III). In the dry season (Fig. 5), B. soporator corresponds to Group I, ingesting mainly tanaidaceans $(>70 \%)$, followed by ostracods (24\%). This species showed a high degree of overlap with two species of Group II, C. boleosoma and C. shufeldti, because both consumed ostracods in large quantities (74 and 57\%, respectively), followed by tanaidaceans (26 and 43\%). The species found among the vegetation showed no dietary overlap in either season.

Food niche breadth. The predominance of species using mainly a single food source (crustaceans, and among these, Ostracoda and Tanaidacea) and the existence of seasonal variation in the diets of some species were quite evident in the analysis of food niche breadth (Tab. V). Dietary specialists predominated.

Ontogenetic variation in diet. For three species it was possible to analyze ontogenetic variation in the general diet (FI\%) and in the kinds of crustaceans consumed (RII\%). Although these three were collected in both seasons of the year, only B. soporator was collected in sufficient numbers $(>5)$ for both ontogenetic and seasonal analysis.

The general diet (Fig. 6) of B. soporator showed no significant ontogenetic or seasonal variation. In both seasons of the year, comparison of the diet of fish in the two size classes showed no significant differences $\left(\chi^{2}=3.7, \mathrm{df}=4, \mathrm{p} \leq 0.05\right.$ and $\chi^{2}=8.6, \mathrm{df}=5, \mathrm{p} \leq 0.05$ for the dry and rainy seasons, respectively); individuals of both classes consumed mainly crustaceans. Similarly, no significant differences were obtained when the seasons were compared within each size class $\left(\chi^{2}=3.0, \mathrm{df}=3, \mathrm{p} \leq\right.$ 0.05 and $\chi^{2}=6.1, \mathrm{df}=4, \mathrm{p} \leq 0.05$ for the larger and smaller classes, respectively).

Analyzing the kinds of crustaceans consumed by B. soporator (Fig. 7), in the dry season the larger fish consumed a higher percentage of tanaidaceans, whereas the smaller fish consumed ostracods and tanaidaceans in similar proportions. Contrariwise, in the rainy season larger individuals had a more diversified diet, whereas the smaller ones consumed mainly tanaidaceans. Although there was a tendency toward ontogenetic variation for $B$. soporator in the kind of crustaceans eaten in each season, the chi-square analysis comparing the diets of the size classes (within the same season) indicated that the values were not significant (dry season $\chi^{2}=3.9$, $\mathrm{df}=4, \mathrm{p} \leq 0.05$; rainy season $\chi^{2}=6.3$, $\mathrm{df}=6, \mathrm{p} \leq 0.05$ ). However, when the seasons were compared within each size class, only the smaller individuals showed significant seasonal variation in diet $\left(\chi^{2}=9.2, \mathrm{df}=4, \mathrm{p} \leq 0.05\right.$ and $\chi^{2}=6.9, \mathrm{df}=6, \mathrm{p} \leq 0.05$ for the individuals of the smaller size class, only the smaller and larger size classes, respectively).

For L. paivai (Fig. 8) and C. boleosoma (Fig. 9) no significant dietary differences between the two size 


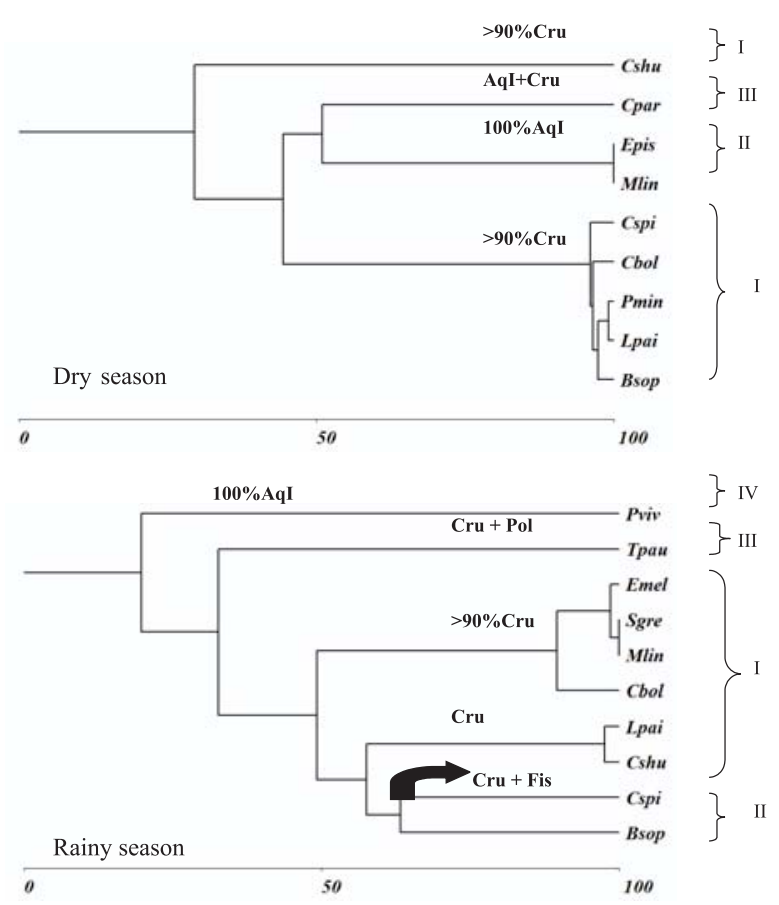

Fig. 4. Dendrogram of similarity (Bray-Curtis) using feeding index $(\mathrm{FI} \%)$ of all food items consumed by the species in the Rio da Fazenda mangrove during the dry and rainy seasons. Acronyms for fish species as in Table I. See text for an explanation of the groups (Roman numerals). (AqI, Aquatic Insects; Cru, Crustacea; Fis, Fish; Pol, Polychaeta).

$>40 \mathrm{~mm} \mathrm{SL} \quad \mathrm{N}=10$

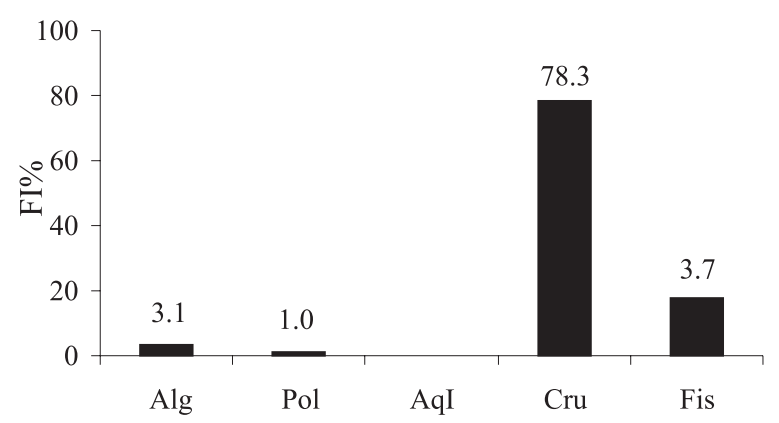

$>40 \mathrm{~mm} \mathrm{SL} \quad \mathrm{N}=8$

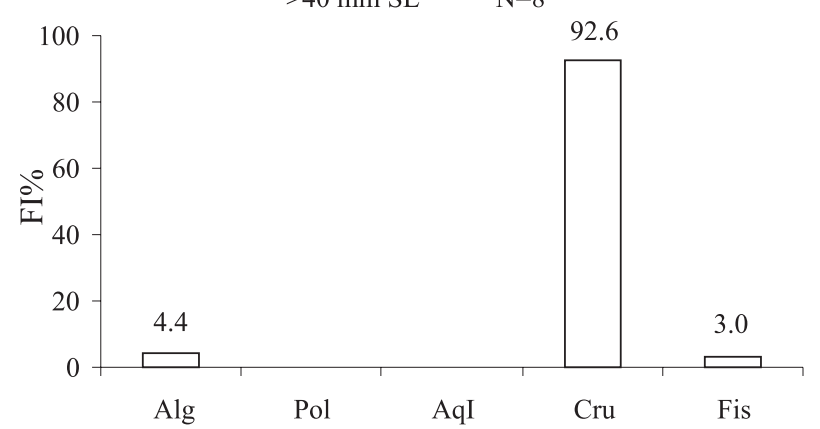

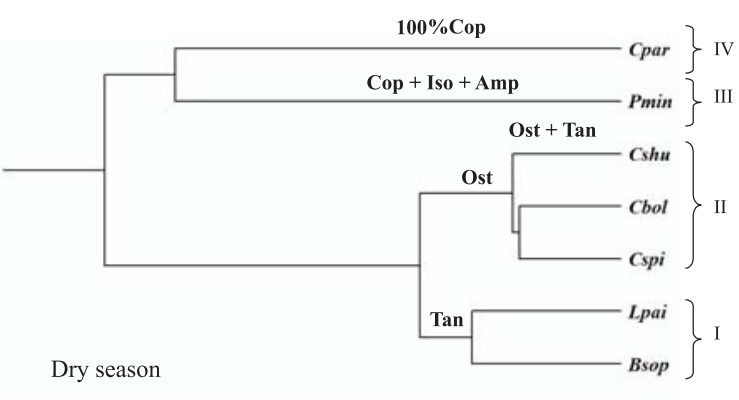

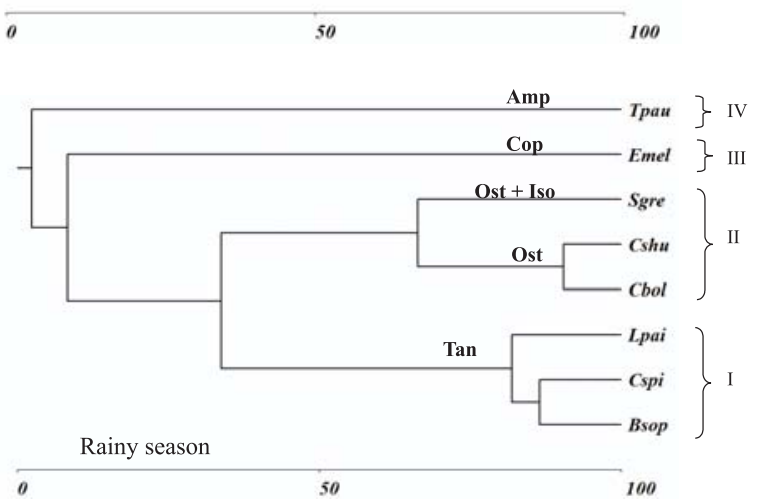

Fig. 5. Dendrogram of similarity (Bray-Curtis) developed from the relative index of importance (RII\%) of the crustaceans consumed by the species collected in the Rio da Fazenda mangrove during the dry and rainy seasons. Acronyms for fish species as in Table I. See text for an explanation of the groups (Roman numerals). (Amp, Amphipoda; Cop, Copepoda; Iso, Isopoda; Ost, Ostracoda; Tan, Tanaidacea).

$<40 \mathrm{~mm} \mathrm{SL} \quad \mathrm{N}=14$

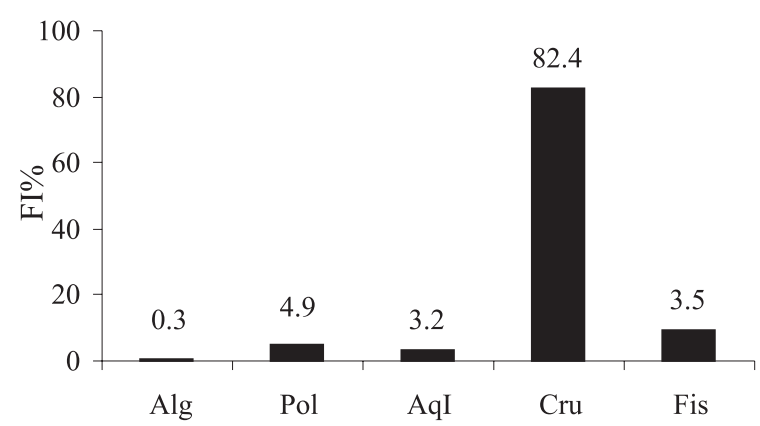

$<40 \mathrm{~mm} \mathrm{SL} \quad \mathrm{N}=7$

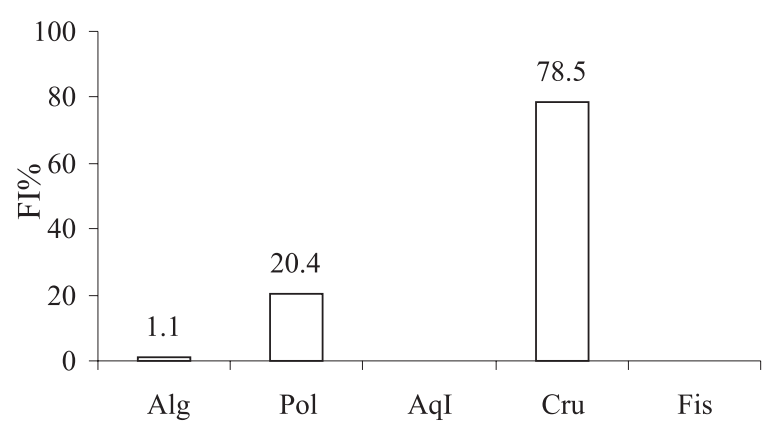

Fig. 6. Feeding Index (FI\%) of all food items consumed by Bathygobius soporator (Valenciennes, 1837) of two size classes (N, number of fish with stomach contents; SL, standard length), sampled in the Rio da Fazenda mangrove during the dry season (white bars) and the rainy season (black bars). (Alg, Algae; AqI, Aquatic Insects; Cru, Crustacea; Fis, Fish; Pol, Polychaeta). 

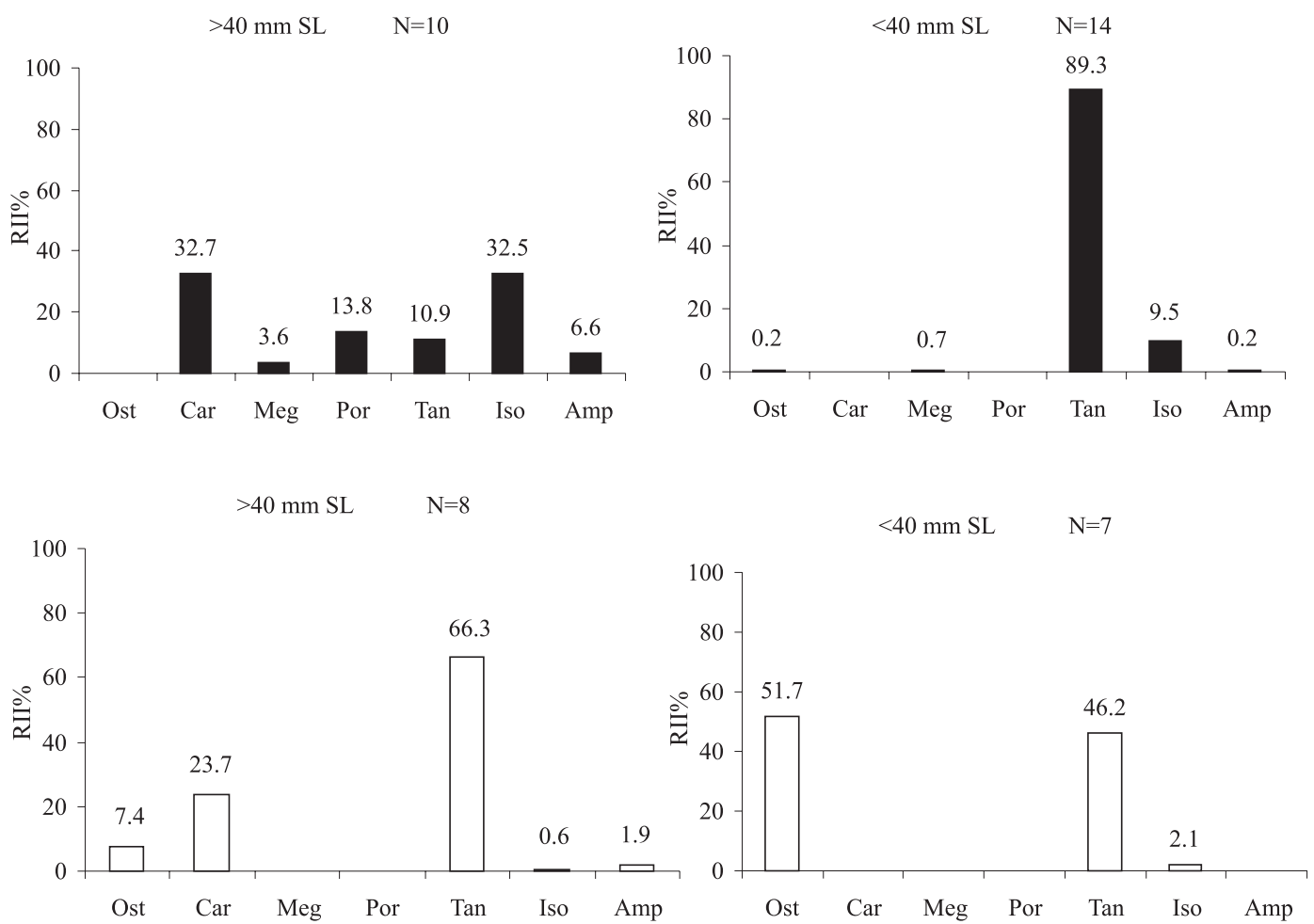

Fig. 7. Relative Index of Importance (RII\%) of the crustaceans consumed by Bathygobius soporator (Valenciennes, 1837) of two size classes (N, number of fish with stomach contents; SL, standard length) sampled in the Rio da Fazenda mangrove during the dry season (white bars) and the rainy season (black bars). (Amp, Amphipoda; Car, Caridea; Iso, Isopoda; Meg, Megalopa; Ost, Ostracoda; Por, Portunidae; Tan, Tanaidacea).
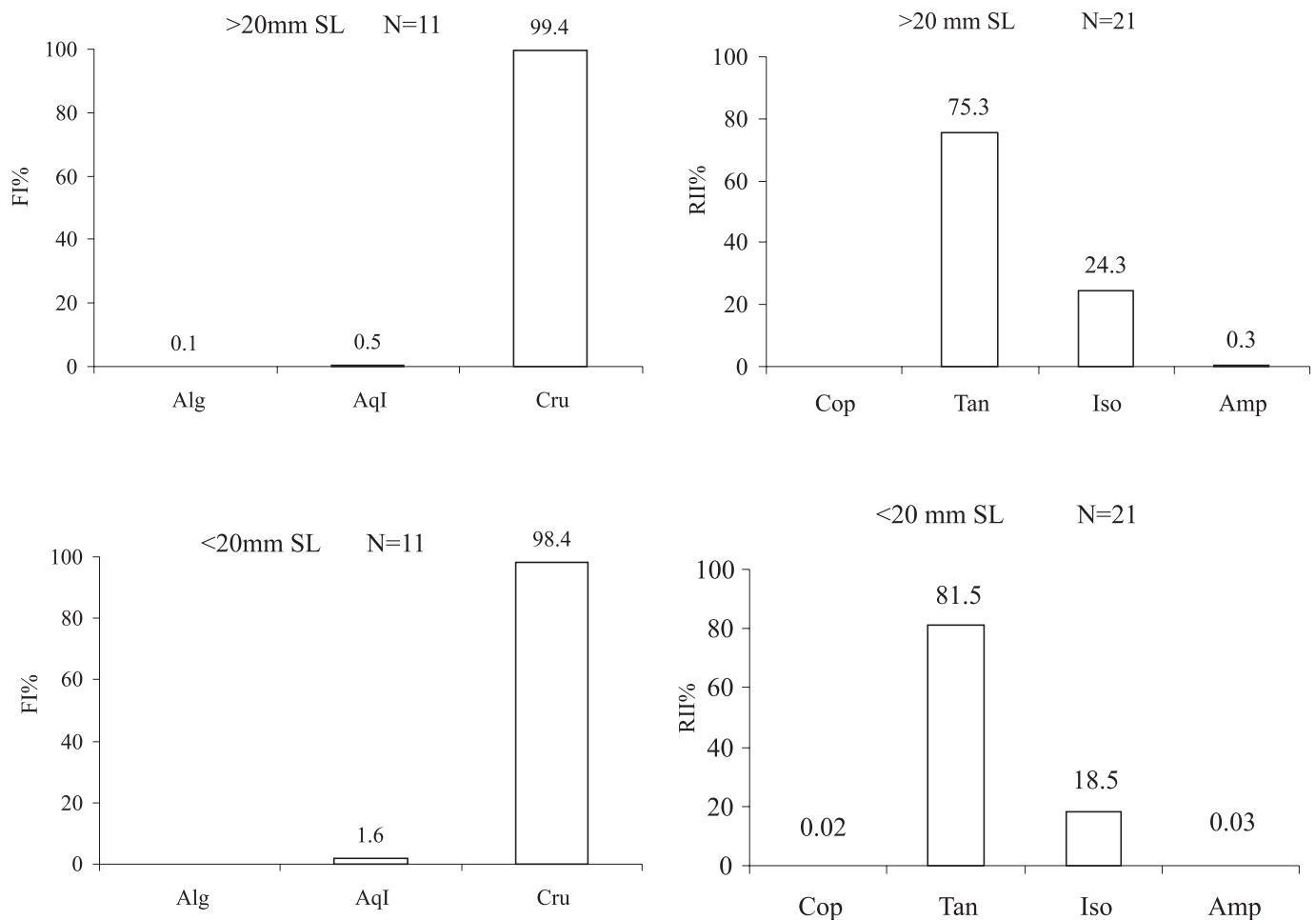

Fig. 8. Feeding Index (FI\%, on the left) of all food items and Relative Index of Importance (RII\%, on the right) of the crustaceans consumed by Lupinoblennius paivai (Pinto, 1958) of two size classes (N, number of fish with stomach contents; SL, standard length) in the Rio da Fazenda mangrove during the dry season. (Alg, Algae; Amp, Amphipoda; AqI, Aquatic insect; Cop, Copepoda; Cru, Crustacea; Iso, Isopoda; Tan, Tanaidacea). 

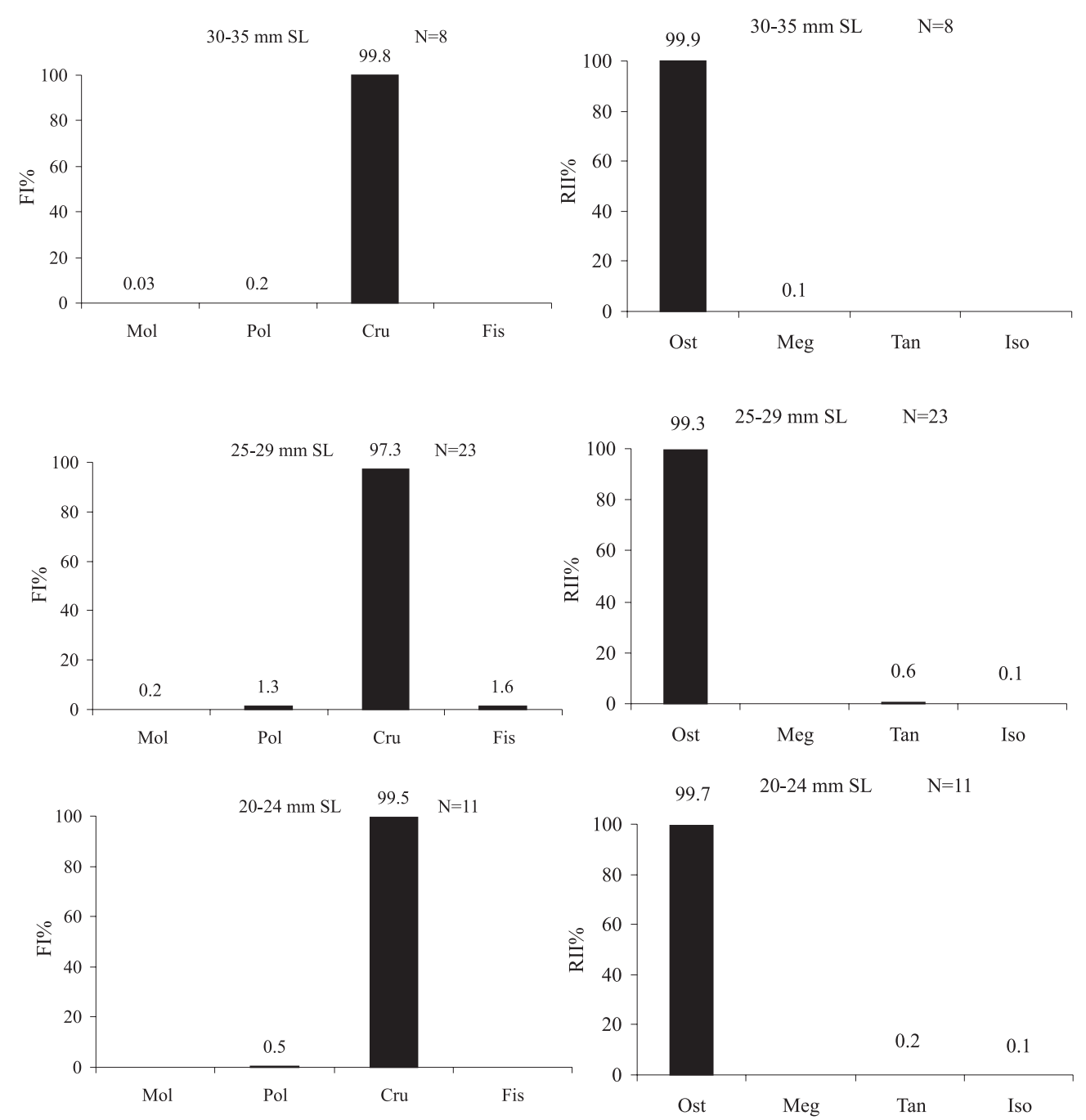

Figure 9. Feeding Index (FI\%, on the left) of all food items and Relative Index of Importance (RII\%, on the right) of the crustaceans consumed by Ctenogobius boleosoma (Jordan \& Gilbert, 1882) of three size classes (N, number of fish with stomach contents; SL, standard length) in the Rio da Fazenda mangrove during the rainy season. (Cru, Crustacea; Fis, Fish; Iso, Isopoda; Meg, Megalopa; Mol, Mollusca; Ost, Ostracoda; Pol, Polychaeta; Tan, Tanaidacea).

Table V. Niche breadth ( $\mathrm{B}_{\mathrm{A}}$, Levins' standardized measure) determined for fish species of Rio da Fazenda, using the Feeding Index (FI\%) and the Relative Index of Importance (RII\%), calculated for the dry season (DS) and the rainy season (RS). Species were considered specialists when $\mathrm{B}_{\mathrm{A}}<0.5$ and generalists when $\mathrm{B}_{\mathrm{A}}>0.5$.

\begin{tabular}{lcccc}
\hline & \multicolumn{2}{c}{$\mathrm{B}_{\mathrm{A}}(\mathrm{FI} \%)$} & \multicolumn{2}{c}{$\mathrm{B}_{\mathrm{A}}(\mathrm{RII} \%)$} \\
Species & $\mathrm{DS}$ & $\mathrm{RS}$ & $\mathrm{DS}$ & $\mathrm{RS}$ \\
\hline B. soporator & 0.053 & 0.436 & 0.321 & 0.191 \\
C. boleosoma & 0.024 & 0.060 & 0.623 & 0.003 \\
C. parallelus & 0.688 & & 0 & \\
C. spilopterus & 0.060 & 0.502 & 0.192 & 0.227 \\
E. melamopterus & & 0.028 & & 0.180 \\
E. pisonis & 0 & & & \\
C. shufeldti & 0.323 & 0.195 & 0.966 & 0.108 \\
L. paivai & 0.018 & 0.386 & 0.116 & 0.280 \\
M. lineatus & 0 & 0 & & \\
P. mindii & 0 & & 0.191 & \\
P. vivipara & \multicolumn{5}{c}{. } & 0 & \\
S. greeleyi & \multicolumn{5}{c}{ paulistanus } & 0.750 & & 0.677 \\
\% Specialists & 83.3 & 71.4 & 66.7 & 85.7 \\
\% Generalists & 16.7 & 28.6 & 33.3 & 14.3 \\
\hline
\end{tabular}

classes were observed, either for the general $\operatorname{diet}\left(\chi^{2}=2.4\right.$, $\mathrm{df}=2, \mathrm{p} \leq 0.05$ and $\chi^{2}=5.5, \mathrm{df}=4, \mathrm{p} \leq 0.05$ respectively), or for the groups of crustaceans consumed $\left(\chi^{2}=0.8, \mathrm{df}=3\right.$, $\mathrm{p} \leq 0.05$ e $\left.\chi^{2}=4.4, \mathrm{df}=3, \mathrm{p} \leq 0.05\right)$. In both size classes, the two species consumed mainly crustaceans ( $>90 \%)$, with $L$. paivai having a preference for tanaidaceans, and $C$. boleosoma for ostracods.

\section{DISCUSSION}

Although it was not possible to assess the diet of the individuals of $M$. curema collected in the Rio da Fazenda, data from specimens sampled in an estuary located at the other end of Fazenda Beach showed that the diet of this species is based on algae, followed by organic matter (Virgínia S. Uieda, pers. obs.). Considering those data, this species did not show feeding overlap with any of the other studied species, for which these food resources were not found (organic matter), or were present in a very low percentage (algae) in the diet. 
Most of the fish species of the Rio da Fazenda mangrove ingested primarily crustaceans. This predominance of crustaceans in the diet of fish in mangrove areas was also noted for gobiids, the family best represented in the study area (AzEvedo \& Simas, 2000). For C. boleosoma and C. shufeldti, the morphological similarities probably influenced the similarity in diets (FITZHUGH \& FLEEGER, 1985; ToEPFER \& FLEEGER, 1995), as also found in the present study.

The generally more diversified diet of the species during the rainy season (cluster analysis), may be related to greater availability of resources in the environment during this period. A pattern of seasonal variation in the diet, influenced by seasonal variation in the availability of resources was also observed for some fish species present in an area just upstream of the upper stretch of the Rio da Fazenda mangrove (Virgínia S. Uieda, pers. obs.), where aquatic insects predominated in the diet during the rainy season, and crustaceans during the dry season.

In the macroinvertebrate fauna present in the submersed roots of the vegetation of the Rio da Fazenda mangrove, isopods (Sphaeromatidae) and tanaidaceans (Tanaidae) were the most important crustaceans (Corrêa \& Uieda, unpublished data). Thus, the greater consumption of ostracods and tanaidaceans by the fish species analyzed must be related not only to their availability in the environment, but also to the viability of consumption. The presence of a more rigid exoskeleton in isopods can make the consumption of this item less advantageous for the fish than crustaceans such as tanaidaceans, which, besides being abundant, have an exoskeleton easier to manipulate. Furthermore, the presence of a certain type of food in the digestive contents of a fish does not necessarily mean that it is a preferred food: it may be ingested only because it is more available, while the preferred food is absent, scarce or hard to catch (ZAVALA-CAMIM, 1996). Therefore, the high consumption of ostracods by the fish of the Rio da Fazenda mangrove, in spite of their low abundance on the submersed roots of the vegetation, may indicate a preference for this group of crustaceans.

In the Rio da Fazenda mangrove, the submerged vegetation along the shoreline was used by the ichthyofauna as a foraging locality, and for bottomfeeding species, mainly as cover. Cover is defined as "whatever thing that provides protection against predators or improves adverse stream flow conditions or seasonal changes in metabolic costs" (HABITAT INVENTORY Committee, 1986). Thus, for bottom species, the vegetation may be being used for protection from aerial and aquatic predators, or even from the pull of the current during changing tides. According to Alves \& FilHo (1996), vegetation can be used as a temporary shelter by active species, and as a substrate, reproduction and refuge by less mobile species. The behavioral interactions between the fish species and their prey may be influenced by the presence or absence of littoral vegetation, which plays an important role in foraging success and in the behavior of predators (SAVINO \& STEIN, 1989).

Ontogenetic variation in the diet of a species during its development is an adaptation that permits reduction of competition for food or to supply physiological needs for migration, sexual maturation and reproduction (BRAGA \& BRAGA, 1987; WINEMILLER, 1989). This adaptation may entail a change in the foraging site, from feeding in midwater to feeding at the bottom, during ontogenetic development (ZAHORCSAK et al., 2000). The lack of ontogenetic variation in the general diet, for the three species analyzed, may be related to similarities in foraging strategy and locale used by individuals of all size classes and to the abundance of the food resources (crustaceans), consumed predominantly by fish of all sizes.

The present study provides evidence that marginal vegetation is important to fish species of the Rio da Fazenda mangrove as a place for shelter and foraging. The high diversity of crustaceans constituted an important food source for the majority of species, which adjusted their diet according to seasonal variations in the availability and to interactions with other species.

Acknowledgements. We are grateful to Hamilton A. Rodrigues for assistance in the field; to Instituto Florestal-Núcleo Picinguaba for the local support and research allowance; to Fundação de Amparo à Pesquisa do Estado de São Paulo - FAPESP for financial support (Proc- 03/08314-2) and for the grants to the first author.

\section{REFERENCES}

Alves, M. I. M. \& Filho, A. A. S. 1996. Peixes do Rio Jaguaribe (Ceará-Brasil): aspectos fisiológicos. Ciência Agronômica 27:5-16.

Azevedo, J. M. N. \& Simas, A. M. V. 2000. Age and growth, reproduction and diet of a sublittoral population of the rock goby Gobius paganellus (Teleostei, Gobiidae). Hydrobiologia 440:129-135.

Barletta, M.; Saint-Paul, U.; Barletta-Bergan, A.; Ekau, W. \& Schories, D. 2000. Spatial and temporal distribution of Myrophis punctatus (Ophichthidae) and associated fish fauna in a northern Brazilian intertidal mangrove forest. Hydrobiologia 426:65-74.

Barletta-Bergan, A.; Barletta, M. \& Saint-Paul, U. 2002. Structure and seasonal dynamics of larval fish in the Caeté river estuary in north Brazil. Estuarine, Coastal and Shelf Science 54:193-206.

Braga, F. M. S. \& Braga, M. A. A. S. 1987. Estudo do hábito alimentar de Prionotus punctatus (Bloch, 1797) (Teleostei, Triglidae), na região da Ilha Anchieta, Estado de São Paulo, Brasil. Revista Brasileira de Biologia 47(1/2):31-36.

Chaves, P. De T. C. \& Bouchereau, J-L. 1999. Use of mangrove habitat for reproductive activity by the fish assemblage in the Guaratuba bay, Brazil. Oceanologica Acta 23(3):273-280.

Chaves, P. De T. C. \& Отto, G. 1999. The mangrove as a temporary habitat for fish: the Eucinostomus species at Guaratuba Bay, Brazil (2552'S; 48³9'W). Brazilian Archives of Biology and Technology 42(1):61-68.

Chong, V. C.; Saserumar, A.; Leh, M. U. C. \& Cruz, R. D. 1990. The fish and prawn communities of a Malaysian coastal mangrove system, with comparisons to adjacent mud flats and inshore waters. Estuarine, Coastal and Shelf Science 31:703-722.

Esteves, K. E. \& Galetti JR., P. M. 1995. Food partitioning among some characids of a small Brazilian foodplain lake from the Paraná River basin. Environmental Biology of Fishes 42:375-389.

Figueiredo, J. L. \& Menezes, N. A. 1980. Manual de peixes marinhos do sudeste do Brasil: Teleostei (2). São Paulo, Museu de Zoologia. v.3, 90p.

Figueiredo, J. L. \& Menezes, N. A. 2000. Manual de peixes marinhos do sudeste do Brasil: Teleostei (5). São Paulo, Museu de Zoologia. v.4, 116p.

Fitzhugh, G. R. Fleeger, J. W. 1985. Goby (Pisces: Gobiidae) interactions with meiofauna and small macrofauna. Bulletin of Marine Science 36(3):436-444. 
Habitat Inventory Committee. 1986. Aquatic habitat inventory: glossary and standard methods. Bethesda, Western Division American Fisheries Society. 134p.

Heck JR, K. L \& Thoman, T. A. 1981. Experiments on predatorprey interactions in vegetated aquatic habitats. Journal of Experimental of Marine Biology and Ecology 53:125-134.

Hyslop, E. J. 1980. Stomach contents analysis-a review of methods and their application. Journal of Fish Biology 17:411-429.

Kawakami, E. \& Vazzoler, G. 1980. Método gráfico e estimativa de índice alimentar aplicado no estudo de alimentação de peixes. Boletim do Instituto oceanográfico 29(2):205-207.

Krebs, C. J. 1989. Ecological Methodology. New York, Harper \& Row. 654p.

LAEgdsgaARD, P. \& Johnson, C. R. 1995. Mangrove habitats as nurseries: unique assemblages of juvenile fish in subtropical mangroves in eastern Australia. Marine Ecology Progress Series 126:67-81.

. 2001. Why do juvenile fish utilize mangrove habitats? Journal of Experimental Marine Biology and Ecology 257:229-253.

Menezes, N. A. \& Figueiredo, J. L. 1980. Manual de peixes marinhos do sudeste do Brasil.: Teleostei (3). São Paulo, Museu de Zoologia, Universidade de São Paulo. v.4, 96p. 1985. Manual de peixes marinhos do sudeste do Brasil. Teleostei (4). Museu de Zoologia, Universidade de São Paulo, v.5, 105p.

Morais, A. T. De \& Morais, L. T. DE 1994. The abundance and diversity of larval and juvenile fish in a tropical estuary. Estuaries 17(1B):216-225.

Morin, B. C. H. \& Whoriskey, F. G. 1992. Environmental influences on seasonal distribution of coastal and estuarine fish assemblages at Wemindji, eastern James Bay. Environmental Biology of Fishes 35:219-229.

Paiva Filho, A. M. \& Toscano, A. P. 1987. Estudo comparativo e variação sazonal da ictiofauna na zona entremarés do mar Casado-Guarujá e mar Pequeno-São Vicente, SP. Boletim do Instituto oceanográfico 35(2):153-165.

Pielou, E. C. 1984. The interpretation of ecological data. New York, Wiley. Biodiversity, 1997 NHM \& SAMS.
Pinkas, L.; Oliphant, M. S. \& Iverson, I. L. K. 1971. Food habits of Albacore, bluefin tuna, and Bonito in California waters. Fish Bulletin 152:1-10.

Robertson, A. I. \& Duke, N. C. 1987. Mangroves as nursery sites: comparisons of the abundance and species composition of fish and crustacean in mangroves and other nearshore habitats in tropical Australia. Marine Biology 96:193-205.

1990. Mangrove fish-communities in tropical Queensland, Australia: spatial and temporal patterns in densities, biomass and community structure. Marine Biology 104:369-379.

SABINo, J. 1999. Comportamento de peixes em riachos: métodos de estudo para uma abordagem naturalística. In: Caramaschi, E. P.; Mazzoni, R.; Bizerril, C. R. S. F. \& Peres-Neto, P.R. eds. Ecologia de Peixes de Riachos. Série Oecologia Brasiliensis. Rio de Janeiro, PPGE-UFRJ. p.83-208.

SAvino, J. B. \& Stein, R. A. 1989. Behavior of fish predators and their prey: habitat choice between open water and dense vegetation. Environmental Biology of Fishes 24(4):287-293.

Statistica v. 6.0. 2001 Statsoft Inc.

Thayer, G. W.; Colby, D. R. \& Hettler, JR., W. F. 1987. Utilization of the red mangrove prop root habitat by fishes in south Florida. Marine Ecology-Progress Series 35:25-38.

Toepfer, C. S. \& FleEger, J. W. 1995. Diet of juvenile fishes Citharichthys spilopterus, Symphurus plagiusa, and Gobionellus boleosoma. Bulletin of Marine Science 56(1):238-249.

Winemiller, K. O. 1989. Ontogenetic diet shifts and resource partitioning among piscivorous fishes in the Venezuelan Llanos. Environmental Biology of Fishes 26:177-199.

Wright, J. M. 1986. The ecology of fish occurring in shallow water creeks of a Nigerian mangrove swamp. Journal of Fish Biology 29:431-441.

Zahorcsak, P.; Silvano, R. A. M. \& Sazima, I. 2000. Feeding biology of a guild of benthivorous fishes in a sandy shore on south-eastern Brazilian coast. Revista Brasileira de Biologia 60(3):511-518.

ZavalA-C АMIM, L. A. 1996. Introdução aos estudos sobre alimentação natural de peixes. Maringá, EDUEM. 129p.

Recebido em setembro de 2006. Aceito em julho 2007. ISSN 0073-4721

Artigo disponível em: www.scielo.br/isz

Iheringia, Sér. Zool., Porto Alegre, 97(4):486-497, 30 de dezembro de 2007 